HSTC Bulletin

Journal of the History of Canadian Science, Technology and Medecine

hstc

Revue d'histoire des sciences, des techniques et de la médecine au Canada

bulletin

\title{
HSTC Newsletter
}

\section{Bulletin d'information HSTC}

Volume 5, numéro 3 (19), septembre-september 1981

URI : https://id.erudit.org/iderudit/800120ar

DOI : https://doi.org/10.7202/800120ar

Aller au sommaire du numéro

Éditeur(s)

HSTC Publications

ISSN

0228-0086 (imprimé)

1918-7742 (numérique)

Découvrir la revue

Citer ce document

(1981). HSTC Newsletter. HSTC Bulletin, 5(3), 228-232.

https://doi.org/10.7202/800120ar

Tout droit réservé (c) Canadian Science and Technology Historical Association / Association pour l'histoire de la science et de la technologie au Canada, 1981
Ce document est protégé par la loi sur le droit d'auteur. L'utilisation des services d'Érudit (y compris la reproduction) est assujettie à sa politique d'utilisation que vous pouvez consulter en ligne.

https://apropos.erudit.org/fr/usagers/politique-dutilisation/ 


\title{
BULLETIN D'INFORMATION HSTC NEWSLETTER
}

\author{
PROCEEDINGS OF THE SECOND KINGSTON CONFERENCE
}

The second Kingston Conference, Critical Issues in the history of Canadian science, technology and medicine, will be held at the John Deutsch University Centre at Queen's University on 6-8 November 1981. In addition to the considerable academic content--eighteen invited papers, four workshops and some twenty-five work-in-progress papers--the conference will also mark the first formal meeting of the fledgling Canadian Science and Technology Historical Association. The CSTHA/AHSTC now numbers 110 historians, archivists, museum personnel and others interested in Canada's scientific and technological heritage. The proceedings of the conference, Critical Issues in the History of Canadian Science, Technology and Medicine/Problemes cruciaux dans l'histoire de la science, de la technologie et de la médecine canadiennes, will, funding permitting, appear in soft cover in the summer of 1982. The volume will contain the invited papers of the conference.

\section{HISTORICAL PERSPECTIVES ON CANADIAN MEDICINE}

A conference on this topic will be held at McMaster University on Thursday, Friday and Saturday, 3-5 June 1982. Papers presented will cover a wide range of Canadian medical historical topics.

The Hannah Institute for the History of Medicine will assist in funding the conference, and it is planned that a conference proceedings will be published with all possible speed. The timing of the conference has been planned so as to just precede the meetings of the Canadian Society for the History of Medicine, the Canadian Historical Association and other related groups at the Learned Societies meetings in ottawa.

Anyone who wishes further details, or who would like their name to be placed on the mailing list for later information, should write to C.G. Roland, MD, McMaster University, History of Medicine, 3H56-HSC, Hamilton, Ontario L8N $3 \mathrm{Z} 5$.

\section{CANADIAN SCIENCE AND TECHNOLOGY AT THE LEARNEDS}

Although the CSTHA/AHSTC cannot officially participate in the meetings of the Learned Societies at ottawa next spring, an opportunity for those interested in reading papers and workin-progress reports on Canadian topics will be available through the Canadian Society for History and Philosophy of Science. Arnold E. Roos, President of the CSTHA/AHSTC is also programme chairman for the CSHPS ottawa meeting and interested persons should contact him at 166 Bayswater Ave., Ottawa, ont. KIY $2 \mathrm{G} 3$. 
An annual event for historians of agriculture in ontario is the Guelph agricultural history conference. The 1981 meeting, held 31 October, featured papers by Gilbert stelter, . 'The Hopes and Realities of Town and Country Planning in Upper Canada: the Case of Wellington County; ' Russell Cooper, 'Recreating the Rural Village;' Leo Johnson, 'The Interrelationship of Town and Country in Ontario County, C.W.;' Edward Noble, 'Barrie and Orillia: the Market Town and the Manufacturing Centre, 1860-1911;' Fred Dahms, 'The Role of the Country Town in Ontario Today: Examples from Wellington and Huron Counties;' and Alvin Koop and Sheila McMurrich Koop, 'Panel: Going to Town--the Value of Oral History.' The proceedings of the first five conferences have been published and are available, at $\$ 6.00$ each, from the Continuing Education Division, University of Guelph, Guelph, ont. NIG 2 Wl.

\section{POSITION IN THE HISTORY OF SCIENCE}

The Department of History, University of Victoria, invites applications for a permanent appointment in the history of science and/or history of technology. Preference will be given to specialists in the interrelationships of science and society. This appointment will be at the associate or full professor rank. Candidates must have a good publication and teaching record and be interested in interacting with colleagues in related disciplines. Rank and salary will be commensurate with the applicant's qualifications and experience. Competition will be closed on 1 February 1982. Letters of application, including a curriculum vitae, should be sent to Dr W. T. Wooley, Chairman, Department of History, University of Victoria, Victoria, B.C., V8W 2 Y 2 .

\section{THESES RECENTES}

Jacques Bernier, de l'Université Laval, nous rapporte les titres de deux thèses soutenues récemment sous là direction de Prof Claude Galarneau:

Michel Verrette, 'L'Alphabetisation de la population de la ville de Québec de 1750 à 1849' (Mâ̂tre ès Arts, 1979)

Ginette Bernatchez, 'Ia Société littéraire et historique de Québec (The Literary and Historical Society of Quebec), 1824-1890' (MaItre ès Arts, 1979).

\section{NEW GOVERNMENT PUBLICATIONS}

The Science Council of Canada has recently (August 1981) released a discussion paper by Donald A. George, An Engineer's View of Science Education, as part of the Science Council's project on science education in Canadian schools. George argues the importance of including the study of applications, 
technology and social implications in science curricula. The report can be obtained free from the Science Council, 100 Metcalfe St., Ottawa, Ont.

The Canada Institute for Scientific and Technical Information (CISTI) has published the ninth (1980-81) edition of its Directory of Federally Supported Research in Universities listing some 10,000 projects funded by the Government of Canada. The two volumes cost $\$ 50.00$ and may be obtained from the Information Exchange Centre, CISTI, National Research Council, Ottawa KIA OS2 (NRC No. 19639). Disponible en français.

\section{ONTARIO HISTORICAL SOCIETY}

\section{MATERIAL HISTORY PROJECT}

The Ontario Historical Society, with support from the ontario Ministry of Culture and Recreation, is undertaking a one-year study of the province's material history. The purpose of this study is to review the current research on industries and crafts in ontario during the 19th and early 20 th centuries. The long-term goal is to assist community museums, historical societies and other history-oriented groups in identifying the significant industries and crafts of their region so that they can develop guidelines for collecting and interpreting this material. Elizabeth Quance has been appointed as the Society's writer/researcher on this project.

The first step in this project will be to prepare an annotated bibliography of Ontario's material history and a resource inventory of unpublished research, archival sources, locations of major collections relating to particular industries and crafts, and the names and addresses of persons researching related topics. When the study is completed, a copy of the results will be made available to historical societies and museums through the Ministry of Culture and Recreation.

The Ontario Historical Society would appreciate your help in making this inventory as complete as possible. If you are doing research on any industry or craft in ontario, or if you are aware of unpublished research or archival material relating to individual manufacturers or craftsmen in ontario, please contact me at the offices of the Ontario Historical Society, 78 Dunloe Road, Toronto M5P 2T6 (telephone 416-486-1232).

Elizabeth Quance Toronto

CSHM CALL FOR PAPERS

The Annual Meeting of the Canadian Society for the History of Medicine will take place at the University of Ottawa in con- 
junction with the Learned Societies on 10-11 June 1982 . All those interested in the history of medicine are invited to participate. Those wishing to give a paper should submit an abstract of 200-300 words (three copies) to Prof Toby Gelfand. Time allotted to each speaker is 20 minutes to be followed by 10 minutes of discussion. We should like to have a special session on the theme of 'Canadian Medical Biography.' Contributions on this subject would be particularly welcome. The programme committee members are Toby Gelfand, Prof Jacques Bernier (Laval) and Barbara Tunis. Forward abstracts to Prof Gelfand, Hannah Chair of the History of Medicine, University of Ottawa, Ottawa KIN 9A9; (613) 231-2360.

\section{CSHPS AND CSHM PAPERS READ AT HALIFAX}

The following are the titles of papers read to the annual meetings of the Canadian Society for History and Philosophy of Science and the Canadian Society for the History of Medicine, 31 May-2 June 1981.

N.B. The HSTC Bulletin cannot supply copies of the papers. Interested readers should contact the authors directly.

Sandra F. McRae (Institute for History and Philosophy of Science and Technology, University of Toronto), 'A.B. Macallum and Evolutionary Physiology: Creating a Canadian Context for New Biological Disciplines;'

Bertrum MacDonald (History of Medicine and Science, University of Western Ontario), 'Sir J.W. Dawson and his Contributions to 19 th Century Palaeobotany; i

Philip Enros (Institute for History and Philosophy of Science and Technology, University of Toronto), 'The Emergence of Industrial Science in Ontario;'

N. T. Gridgeman (retired-National Research Council), 'The Burgeoning of Chemistry in Canada;'

Robert V. V. Nicholls (retired-McGill University), 'Canada's Contribution to RDX, Super Explosive of World War II;'

Ernest Stieb (Faculty of Pharmacy, University of Toronto), 'The Niagara Apothecary at the Sign of the Golden Mortar;'

S.E.D. Shortt (History of Medicine, Queen's University), 'Medical Professionalization: Pitfalls and Promise in the Literature;'

Charles G. Roland (History of Medicine, McMaster University), The Canadian Medical Journal: Communication of Medical Information in 19th Century Canada;'

Barbara Tunis (University of Ottawa), 'Lower Canada: Professionalization of Medicine, 1788-1840;'

Colin Howell, 'Professionalization and the Progressive Reform Impulse: Reform, Professionalism and the Medical Profession in Maritime Canada, 1880-1914.' 


\section{PARKS CANADA HISTORICAL RESEARCH}

In the last issue I listed some of the recent titles produced by Parks Canada researchers. The following list of manuscripts are not publications but, as their title Manuscript Report Series/Travails inédits suggests, unedited works that have been put between soft covers to facilitate internal distribution. A copy of these manuscripts is distributed to a number of archives and special depositories across Canada where they are available for public use. They cannot be bought or otherwise obtained from the government. Those works which are deemed to be of wider interest generally find their way into official Parks Canada publications such as Canadian Historic Sites and Occasional Papers in Archaeology and History, both of which are publiclydistributed journals.

Yves Tremblay, 'Etudes de la maison du moulu Forges du StMaurice' (TI 366)

William Wylie, 'Elements of a Military Heritage: A Structural History of the Merrickville and Newboro Blockhouses, the Jones Falls and Whitefish Guardhouses, and the Jones Falls Defensible Lockmaster's House.' (MRS 372)

Richard G. Stuart, 'Dawson City: Three Structural Histories.' (MRS 383)

Lila Lazoe (introduction Robert Burns), ' Artifacts, Consumer Goods and Services Advertised in Kingston Newspapers, 1840-50: A Resource Tool for Material History Research.' (MRS 397)

Claire Mousseau, 'L'évolution fonctionelle de la forge haute à travers la transformation des ouvrages, 1739-1883.' (TI 398)

Arnold E. Roos, 'A Narrative History of the SS Klondike.' (MRS 402)

Richard Tatley,'Kingston Mills.' (MRS 413)

Cyrille Gélinas, 'Réflexions préliminaires à une étude de la vallée du richlieu: quelques observations générales sur trois siècles d'agriculture et d'exploitation forestière.' (TI 414)

Yvon Desloges, 'La construction du Fort Lévis, no. 1, SaintJoseph de la Pointe-Lévis, 1865-1872.' (TI 415) 